\title{
Entrepreneurship Education as Correlates of Desire and Intention for New Venture Creation
}

\author{
Paul Ayobami Akanbi, \\ Associate Professor and Acting Head, Department of Business Administration, Faculty of Management Sciences, \\ Ajayi Crowther University, Oyo
}

\begin{abstract}
This research work investigated the influence of Entrepreneurship Education on the Desire and Intention for New Venture Creation. The objectives of the research work were to ascertain whether desire for taking entrepreneurship education, confidence in venture creation and knowledge of venture creation jointly and independently predicted desire and intention for new venture creation, and to establish the link between these variables and the desire and intention for venture creation.

The study employed survey research with questionnaire as research instrument. The subjects were one hundred and fifty 300 and 400 level students of Ajayi Crowther University Oyo, Oyo state. The subjects were selected using a stratified random sampling method. The hypotheses of this research work were analyzed using multiple regression and Pearson's correlation.

Findings from the study showed that the linear combination of Knowledge of Venture Creation, Confidence in Venture Creation and Desire for taking Entrepreneurship Education and Desire and Intention for new Venture Creation was significant at $F=319.789 ; R=.932, R^{2}=.868$, Adj. $\left.\mathrm{R}^{2}=.865 ; \mathrm{P}<.01\right)$. The study also showed that there is a significant relationship between Confidence in Venture Creation and Desire and Intention for new Venture Creation $\left(r=.214^{* *}\right.$, $\mathrm{N}=150, \mathrm{P}<.01)$. Furthermore, there is a significant relationship between Knowledge of Venture Creation and Desire and Intention for new Venture Creation $\left(\mathrm{r}=.681^{* *}, \mathrm{~N}=150, \mathrm{P}<.01\right)$. The study also revealed that there is a significant relationship between desire for taking entrepreneurship education and Desire and Intention for new Venture Creation $\left(r=.852^{* *}, \mathrm{~N}=\right.$ $150, \mathrm{P}<.01)$.

The study concluded that knowledge of entrepreneurial education are predictors of the desire and intention for venture creation. It is therefore recommended that adequate attention be given to entrepreneurship education by institutions and government because it can determine entrepreneurial intention and ultimately entrepreneurial success.
\end{abstract}


Keywords: entrepreneurship education, knowledge of venture creation, venture creation, entrepreneurial intention and entrepreneurial success 